\author{
Marquette University \\ e-Publications@Marquette
}

Political Science Faculty Research and

Publications

Political Science, Department of

7-2017

\title{
The Dual Role of State Attorneys General in American Federalism: Conflict and Cooperation in an Era of Partisan Polarization
}

Paul Nolette

Marquette University, paul.nolette@marquette.edu

Follow this and additional works at: https://epublications.marquette.edu/polisci_fac

Part of the Political Science Commons

\section{Recommended Citation}

Nolette, Paul, "The Dual Role of State Attorneys General in American Federalism: Conflict and Cooperation in an Era of Partisan Polarization" (2017). Political Science Faculty Research and Publications. 53.

https://epublications.marquette.edu/polisci_fac/53 


\title{
The Dual Role of State Attorneys General in American Federalism: Conflict and Cooperation in an Era of Partisan Polarization
}

\author{
Abstract: A key development during the Obama Administration was the increasing \\ importance of state attorneys general (AGs) in national policymaking. This article examines the \\ dual roles that AGs played during the Obama years. The first role was highly contentious, with \\ Republican AGs leading several multistate challenges to Obama Administration priorities and \\ successfully limiting Obama's policy legacy. The second role was more cooperative, involving \\ increasing coordination between AGs and their federal counterparts in national enforcement \\ efforts. Relying on case studies in the areas of immigration enforcement, climate change \\ regulation, and the oversight of for-profit higher education, this article highlights several crucial \\ trends concerning the activities of these important state-level actors.
}


Throughout Barack Obama's presidency, the partisan divides that have been a staple of contemporary American politics continued to widen. The two parties are further apart ideologically now than they have been in decades, as both political elites and members of the mass public have become increasingly polarized (Theriault 2008; Iyengar and Westwood 2015). Scholars examining these trends in political polarization have noted how they have trickled down to the states and affected state-level institutions. State legislatures, for example, have become increasingly polarized in recent years (Shor and McCarty 2011; Jordan and Bowling 2017). This state-level polarization has contributed to a "fragmented federalism" marked by more contentious relationships both between states and the federal government as well as among the states themselves (Bowling and Pickerill 2013).

This article considers how these trends have affected a set of state-level actors who have gained additional prominence during the Obama years: state attorneys general (AGs). Building upon their successes during previous administrations, AGs became a more entrenched part of the national policy landscape during Obama's presidency. Most prominently, coalitions of mostly Republican AGs aggressively challenged Obama Administration initiatives such as the Clean Power Plan, various aspects of the Affordable Care Act, and new rules pertaining to transgender rights. Many of these efforts successfully limited, delayed, or curtailed Obama's regulatory agenda, particularly during his second term. Meanwhile, Democratic AGs used their powers to try to achieve national policy gains, including through corporate investigations of energy companies they accused of thwarting efforts to address climate change.

This AG activism reverberated throughout the American political landscape, frequently sparking partisan responses. Republican and Democratic AGs frequently squared off in court along partisan lines to oppose their fellow AGs' efforts. State legislators and governors battled 
with their state AGs (who are independently elected in most states) over the right to represent their states in litigation, and AGs were criticized both for their willingness to bring litigation and their refusal to defend their state in cases involving hot-button issues such as same-sex marriage, voter ID laws, and political redistricting (e.g., Jarvis and Blythe 2016). Congress even became involved in state-level investigations for the first time, with members of Congress going as far as to issue subpoenas to AGs accused of harassing corporations (Schwartz 2016b).

While this partisan conflict among AGs grew during the Obama Administration, AGs still engaged in a significant degree of cooperative, bipartisan behavior. AGs worked together on several investigations of corporate entities throughout this period, including on important antifraud initiatives, crime control, and drug policy. Additionally, from the first weeks of the Obama presidency, the U.S. Department of Justice (DOJ) signaled that it would seek closer relationships with its state counterparts to tackle issues of common concern of the federal and state governments. This led to the creation of new collaborative efforts including the Financial Fraud Enforcement Task Force, which (among many other efforts) concluded a major \$26 billion settlement with the nation's five largest mortgage lenders over allegations stemming from the mortgage crisis.

This article examines both the conflictual and cooperative aspects of AG activities during Obama's presidency. It builds upon recent scholarly work exploring the institutional development of AGs and their increasing prominence in national policymaking. This increasing prominence in national politics began as early as the 1980s, when groups of AGs began working cooperatively to solve issues of concern to multiple states. Cornell Clayton noted how the "New Federalism" of the 1970s and 1980s reshaped the office by thrusting additional responsibilities on AGs. While AGs were once state-focused actors largely disconnected from one another, AGs 
created new mechanisms of interstate collaboration to help them handle their growing role in national policymaking (Clayton 1994, 542). The crucial breakthrough came in the late 1990s, when forty-six AGs signed a \$206 billion settlement with the tobacco industry that fundamentally altered tobacco policy and regulation in the United States (Derthick 2012). By working together across state lines, AGs pooled their resources, provided legal heft to novel legal arguments, and found success in court against a major industry that private plaintiffs had unsuccessfully battled for decades.

AGs have since used this cooperative multi-state model to influence national policy in several other ways. Building upon their tobacco success, entrepreneurial AGs sought to reshape industry practices in the name of consumer protection (Provost 2003; 2006). Particularly during the George W. Bush Administration, AGs also became more aggressive in employing multistate strategies against the federal government. Activist Democratic AGs such as New York's Eliot Spitzer led numerous campaigns to prevent attempts at regulatory rollback by federal agencies, particularly concerning environmental policy (Nolette 2015a). AGs also became among the most active filers of amicus curiae briefs in federal courts - activity that has become increasingly partisan since the beginning of the 2000s (Lemos and Quinn 2015). All of this building activity since the late 1990s set the stage for AGs to be critical players on the national stage during the Obama Administration.

This activity was made possible in part by Congress's decision to structure much of the contemporary regulatory state on the frame of cooperative federalism, thereby granting state and local governments key roles in the administration of federal policy. States are on the front lines of implementing much of the American environmental and health care policy regimes, for example, such as with enforcing clean air standards or administering Medicaid. This choice 
required federal and state actors to work together to solve common problems, but it also provided states additional leverage to pursue their own agendas within these policy regimes and to make demands on the federal government. Among other things, it led to the creation of new mechanisms of coordination and compromise among and between levels of government, such as the rise of negotiated waivers allowing for state-by-state variation in implementation of federal law (Thompson and Gusmano 2014; Wong 2015).

The increasing institutional resources available to the AGs has also enabled their activism. In addition to creating new avenues of collaboration amongst themselves, AGs have been aided by other institutions and actors that have encouraged state litigation. The federal judiciary, for example, granted states "special solicitude" when determining whether states had standing to sue, making it easier for AGs to use the courts in challenges to national policy. This standing doctrine, a key part of the Supreme Court's decision in Massachusetts v. EPA, 549 U.S. 497 (2007), offered a hook for AGs to bring challenges to new Obama-era laws and regulations. At the same time, Congress continued to bolster AG power during the Obama years, providing AGs additional powers to enforce federal consumer protection laws. State legislatures also frequently allied with their state's AGs, providing additional resources and legal authority to bring lawsuits against corporations and the federal government alike. Meanwhile, ideological interest groups increasingly viewed AGs as powerful allies, providing strategic and financial support for multistate AG litigation (Nolette 2014).

This article examines how trends in AG activity that had been building since the late 1990s became an entrenched part of the national policy landscape during Obama's presidency. During this time, AGs of both parties fully realized the benefits of collective action, taking advantage of collaborations amongst themselves - sometimes along partisan lines and other 
times on a bipartisan basis - to provide rapid responses to federal actions or corporate activities. The scope of their collaborations has also encompassed policy areas in which states traditionally played a smaller role vis-à-vis the federal government, particularly immigration. This increased coordination has allowed AGs to act quickly as well as provide greater support for novel legal arguments.

Their efforts reflect their importance as both key veto points and opportunity points in contemporary American federalism (Wittes and Nivola 2015). On the one hand, their activities have contributed to national policy "gridlock" by delaying or stopping implementation of federal laws and regulations. In the last years of the Obama Administration - and first few months of the Trump Administration - AGs took advantage of the increasing willingness of single federal district courts to issue national injunctions that blocked policies nationwide (Bray forthcoming). On the other hand, AGs have used their positions to circumvent gridlock by acting as opportunity points for policy change when Congress is unwilling or unable to act. Through lawsuits and settlements with corporate defendants, such as the for-profit education sector discussed in this article, AGs have shaped the regulatory environment of entire national industries in the absence of new federal laws or regulations. In this sense, the increasing polarization of state level politics might open more opportunities for policy change, even as polarization in Congress stymies lawmaking.

This article proceeds by first examining the trends towards greater conflictual relationships between the AGs and the federal government as well as among the AGs themselves. Following an overview of partisan AG-led lawsuits against Obama Administration policies and the broader trends they highlight, I turn to two case studies illustrating the contentious side of contemporary AG activism. The first examines Texas v. United States, in 
which several Republican AGs successfully halted two centerpieces of President Obama's immigration policies. The second explores AGs' role in climate change policy, including a multistate AG effort in West Virginia v. EPA that blocked Obama's efforts to institute stricter limits on greenhouse gases. While that effort was largely Republican, Democratic AGs used the powers of their office to begin a novel investigation of ExxonMobil for allegedly interfering with climate science.

While this illustrates the growth of increasing conflict in AG activism, the next section considers how important elements of AG activities remain cooperative and bipartisan. Especially important was the increased use of federal-state enforcement taskforces during the Obama Administration in which federal and state actors worked together to address common concerns. Following an overview of this activity, I turn to a case study examining joint federal-state enforcement actions in the for-profit higher education industry. This highlights a more cooperative side of the relationship between AGs and their federal counterparts.

Analyzing these trends provides insight into how AGs' increasingly prominent role on the national stage both complicates and complements the operation of contemporary national policy. This role reflects deepening "trickle-down polarization" as partisanship on the national level has been increasingly reflected in the states, but also highlights that cooperative efforts aiming to solve shared problems remains possible even in this increasingly polarized era.

\section{POLARIZATION AND CONFLICT IN AG ACTIVITY}

As noted above, polarization among AGs has been building since AGs became more involved in national politics and policy. Shortly after the tobacco litigation, for example, AGs formed separate partisan organizations that have since become important organizations for 
fundraising and strategy development, with the Republican Attorneys General Association forming in 1999 and the Democratic Attorneys General Association forming in 2002. During the George W. Bush Administration, AG activism was often driven by Democratic AGs seeking to fill what they viewed as "regulatory gaps" left open by federal inaction in areas including climate change, prescription drug regulation, and consumer protection. Prominent Democratic AGs such as Eliot Spitzer, who was empowered in part because of Wall Street's presence in New York and also because of the particularly broad nature of the New York AG's legal powers, used numerous innovative legal theories as a method of pushing back on the deregulatory agenda of the Bush Administration.

With a new Democratic administration entering the White House in 2009, Republican AGs essentially flipped the script. In a mirror image of Democratic efforts to push back on deregulatory efforts of the Bush Administration, Republican AGs sought to stymie President Obama's regulatory expansions. The key initial collaboration involved working on a potential challenge to the so-called "Cornhusker Kickback" that was part of the original version of the Patient Protection and Affordable Care Act (ACA). ${ }^{1}$ While this provision was dropped from the final legislation, this initial collaboration eventually blossomed into a multistate effort raising several constitutional challenges to the ACA. ${ }^{2}$ Among other arguments, the states' lawsuit claimed that the Medicaid expansion provision of the ACA violated federalism principles by essentially forcing the states to go along with a federal program. These arguments ultimately succeeded in limiting the ACA's Medicaid expansion by allowing states to opt out of the expansion, which subsequently set up contentious state-level fights over heath care provision. The ACA litigation also presaged later AG challenges to other Obama-era policies. To give a 
sense of the expansiveness of these multistate AG challenges, Table 1 highlights several of the most prominent AG-led lawsuits against Obama Administration policies.

[Table 1 about here]

\section{Recent Trends Towards Greater Conflict in AG Activities}

The emergence of a distinctly Republican AG activism is perhaps the most prominent trend in AG activity that emerged during the Obama Administration. This trend contrasts with the comparatively subdued Republican AG activity during the previous Democratic presidential administration. Republican AGs attempted few multistate challenges to President Bill Clinton's regulatory and legislative program, and even most of these were bipartisan efforts. ${ }^{3}$ Republican AGs formed the Republican Attorneys General Association in 1999 largely in response to the alleged "regulation through litigation" engaged in by liberal AGs; but this organization focused initially on fundraising goals rather than litigation strategy (Curriden 1999). With a Republican president subsequently entering office, Republican AGs took a mainly reactive approach, defending against challenges brought by increasingly aggressive Democratic AGs. Obama's presidency provided Republican AGs an opportunity to go on the offensive. Collaboration on ACA litigation, combined with the 2010 elections that swept a new activist group of conservative AGs into office, entrenched Republican AGs as a strong force against federal regulatory expansion. ${ }^{4}$ In addition to collaborating on direct legal challenges to the Obama Administration, Republican AGs filed scores of multistate amicus briefs in federal courts concerning several highly contentious issues and were active in multistate attempts to affect the regulatory process (Nolette 2014). 
Related to the rise of Republican AG activism was a second major trend: deepening polarization among AGs themselves. As both liberal and conservative AGs have increasingly used their offices to challenge federal policy, it has spurred AGs on the other side of the partisan divide to form counter-coalitions directly opposing the efforts of their fellow AGs. During the ACA litigation, for example, an entirely Democratic coalition of AGs formed to defend the law in court against the entirely Republican AG coalition challenging it. ${ }^{5}$ As challenges to Obama's policies became regularized, the shape of these partisan coalitions has become quite predictable and stable. Similar counter-coalitions formed in response to virtually all of major legal lawsuits initiated by Republican AGs against Obama Administration policies - a divide that also appears in amicus filings in the Supreme Court (Nolette 2014).

The polarization among the AGs themselves has been accompanied by strengthening collaborations between AGs and ideological allies both inside and outside government. During the ACA litigation, for example, AGs worked closely with the National Federation of Independent Business and other business groups throughout the litigation. These collaborations included both discussions about legal strategies as well as pooling financial resources allowing the coalition to hire prominent outside attorneys to direct the lawsuits (Elmore 2011). Democratic AG coalitions have included similar collaborations with liberal interest groups, such as environmental and health care advocacy organizations. For example, the 2007 Massachusetts v. EPA litigation involved close collaboration between the twenty-nine state and interest group plaintiffs aligned against the EPA in the case. Meanwhile, AGs have increasingly coordinated with ideological allies within government as well. In several AG-led lawsuits, members of Congress filed amicus briefs along partisan lines bolstering the arguments made by their statelevel ideological allies. As discussed further below, congressional committees have even gotten 
directly involved in state-level investigations, using their subpoena power to advance the goals of like-minded AGs.

I turn now to a pair of case studies, involving immigration and climate change, that illustrate the intensification of AG conflict during the Obama Administration. As Table 1 indicates, these areas reflect only two of the many in which AGs led challenges to Obama's policies. I focus on immigration and climate change in part because they represent perhaps the two most important substantive areas of policy in which Obama attempted to use executive authority to secure significant policy gains even in the face of congressional hostility. That AGs successfully stymied these crucial aspects of Obama's legacy is an indication of AGs' importance in contemporary American politics.

Additionally, both cases are excellent examples of the sorts of novel argumentation that has become a feature of multistate AG activism. Texas $v$. United States was the most aggressive attempt of AGs yet to influence a policy regime not built upon the structure of cooperative federalism but that had instead been controlled chiefly by the federal government. Relying upon innovative arguments about why they had standing to challenge the federal government in this area, Republican AGs ironically paved the way for successful Democratic AG challenges to immigration orders issues in early part of the Trump Administration. Unlike with immigration policy, environmental policy has been built upon a frame of cooperative federalism. Yet the AGs' climate change litigation illustrates how the cooperative model - by granting states key roles in national policy regimes - also contributes to partisan conflict as AGs have become more polarized. Partisan groups of AGs have employed both the veto points and opportunity points inherent in America's federal system to both push back on federal policy and try to circumvent Congress when it declined to create new policies. 
Disrupting Federal Executive Action: AGs and Obama's Immigration Policy

Immigration has been one of the most polarizing issues in American politics over the last few years, and that polarization has been reflected in AG responses to federal actions concerning the issue. Opposing coalitions of AGs faced off against each other along partisan lines when the federal Department of Justice challenged new state laws in Arizona and elsewhere pertaining to undocumented immigrants (Arizona v. United States, 132 S. Ct. 2492 [2012]). Most prominently, AGs led a major challenge to the Obama Administration's attempts to achieve changes in the immigration system through executive actions taken in the absence of new congressional legislation. This challenge, Texas v. United States, illustrates the emergence of Republican AG activism and the deepening polarization among AGs. It also demonstrates the AGs' increasing involvement in issues, such as immigration, traditionally viewed as within national control.

\section{Obama's Executive Actions and Subsequent AG Challenges}

Texas v. U.S. challenged a series of Obama Administration executive actions following failed congressional efforts to enact the DREAM Act, legislation that would have allowed undocumented immigrants to apply for lawful permanent resident status. Two programs were particularly relevant to the litigation: the Deferred Action for Childhood Arrivals (DACA) program and the Deferred Action for Parents of Americans and Lawful Permanent Residents (DAPA) initiative. DACA, implemented by the Department of Homeland Security (DHS) in 2012, permitted individuals who first came to the US as children to apply for deferred action status and employment authorizations for a renewable two-year period. In November 2014, the DHS announced an expansion of DACA, removing an age cap in the original program that 
excluded some older undocumented immigrants and expanded work authorizations from two to three years. The DHS simultaneously announced the new DAPA program that sought to indefinitely delay deportation of the undocumented immigrant parents of lawful U.S. citizens and permanent residents. DAPA, while not granting any new legal status, would effectively allow approximately four million undocumented immigrants to remain in the country. Both DAPA and the expanded DACA relied upon the exercise of prosecutorial discretion by aiming to cut back on aggressive deportation actions.

Only a few days after the Obama Administration announced both actions, Texas AG Greg Abbott announced that he was leading a seventeen-state coalition challenging the executive actions in the U.S. District Court for the Southern District of Texas. The coalition, which soon expanded to twenty-six states, argued that both directives directly harmed the states by leading to a "flood of immigration across the Texas-Mexico border." This, in turn, threatened to bolster drug cartel activity within Texas and other states and force states to "expend substantial resources on law enforcement, healthcare, and education." The authorization of undocumented immigrants to obtain work permits would also raise additional permit processing costs for the states, and the grant of deferred action would increase costs relating to issuance of drivers' licenses to the beneficiaries of the program. ${ }^{6}$

The plaintiff AGs made two main sets of legal arguments, one constitutional and one statutory. First, the plaintiffs claimed that the actions violated the Take Care Clause in Article II of the Constitution because they amounted to changing the law as opposed to simply using discretion to shape its enforcement. In particular, the AGs pointed to several immigration laws that they argued placed a mandatory duty on the executive branch to deport individuals not in the country legally. Furthermore, Congress had already specified a procedure for undocumented 
parents of U.S. citizens or legal permanent residents to stay in the United States. Contravening these congressional procedures, the states argued, was not within the president's power to "faithfully execute the law." In addition to this constitutional argument, the AGs argued that the administration had violated the procedures for creating new rules required by Administrative Procedure Act (APA). For most rules, the APA requires that the agency provide notice of its proposed rules and an opportunity for affected parties to comment on them. Because neither DACA nor DAPA went through this notice-and-comment rulemaking, the states argued, the agency had illegally sidestepped statutory requirements. The AGs made a substantive APA argument as well, arguing that even if the Administration had followed the APA's procedures, the orders would still be invalid because the DHS' actions essentially rewrote the law as opposed to enforcing it. ${ }^{8}$

Of the twenty AGs involved in the challenge, all but one were Republican. ${ }^{9}$ The additional state plaintiffs included the governors of several states whose AG declined to join the lawsuit. Throughout much of the litigation, this Republican coalition faced off against a sixteenmember all-Democratic AG coalition that defended the Obama Administration's actions through amicus curiae filings. Democratic AGs argued that far from hurting states, DACA and DAPA would actually benefit states by increasing state income tax revenues, improving public safety, and providing a more secure living situation for resident children of undocumented immigrants. ${ }^{10}$ Additionally, they argued that several of the alleged harms suffered by states - such as additional costs accrued because of the issuance of driver's licenses to undocumented immigrants - were self-inflicted since neither federal initiative required states to issues such licenses to undocumented individuals. $^{11}$ 
[Table 2 about here]

\section{The Courts' Decisions}

On February 16, 2015, the District Court issued a preliminary injunction against DAPA and the expanded DACA, upholding the stay a couple months later. The court rejected the Obama Administration's position that both executive actions merely represented the exercise of the DHS's broad discretion to implement immigration law. Instead, Obama's executive actions were less like administrative discretion and more like a substantive rule that - like most regulatory changes - must go through the processes established by the APA. While the APA allows for "general statements of policy" to avoid notice-and-comment rulemaking, these immigration orders spurred a substantive change in existing law, had a binding effect on DHS practice, and thus were subject to the APA. Because the DHS failed to subject the orders to the APA, the orders were invalid. (Because the court held that the federal government had violated the APA's procedural requirements, the court declined to address the constitutional Article II arguments.) Enjoining the program was appropriate since "without a preliminary injunction...the States [would face] the substantially difficult - if not impossible - task of retracting any benefits or licenses already provided to DAPA beneficiaries. This genie would be impossible to put back into the bottle" (Texas v. United States, 86 F. Supp. 3d 591, 673 [S.D. Tex. 2015]).

On appeal, a divided three-member panel of the Fifth Circuit upheld the injunction on November 9, 2015. The lengthy decision mirrored much of the District Court's holding, holding that the plaintiff states were likely to prevail on their claims that the executive actions improperly sidestepped the APA's requirement of notice-and-comment rulemaking. However, the majority went beyond the District Court by also accepting the states'substantive APA claims and 
criticizing the federal government's interpretation of the Immigration and Naturalization Act (INA). Per the majority, "the INA flatly does not permit the reclassification of millions of illegal aliens as lawfully present and thereby make them newly eligible for a host of federal and state benefits, including work authorization" (Texas v. United States, 809 F.3d 134, 184 [5th Cir. 2015]). In short, even if DHS had properly followed the APA's procedural rules - which the Fifth Circuit held it did not - the orders would still be invalid because the INA did not provide DHS the broad authority it claimed when issuing the orders.

The DOJ sought review of this Fifth Circuit panel decision in the Supreme Court, and the Court granted certiorari not only on the APA issues decided by the lower courts but, intriguingly, on the Take Care Clause issue as well. This seemingly set the stage for a major decision in the summer of 2016, but Justice Antonin Scalia's death only a few weeks after the cert grant cast doubt on how the Court would proceed. The answer came on June 23, 2016, when the Court, in a single sentence holding with no reasoning provided, upheld the Fifth Circuit by an equally divided (four-four) court.

The Supreme Court's split decision by an eight-member court upheld the District Court's original stay of DAPA and the expanded DACA. The Court's denial of a rehearing on the first day of its 2016-2017 term effectively put an end to the programs. This was a considerable blow to Obama's overall immigration legacy, and ensured that the question of how to handle millions of undocumented immigrants would be deferred to the Donald Trump Administration. While the Trump Administration had not as of this writing reversed the programs as he had pledged to do during the presidential campaign, the new administration's different approach to immigration issues appears likely to vindicate the plaintiff AGs' litigation strategy of forcing delays in policy implementation. 


\section{$\underline{\text { AG Activism and State Standing }}$}

The Texas v. U.S. litigation helps illustrate the polarized nature of AG activism during the Obama Administration. As they have in numerous policy areas, Republican AGs have harnessed coordinated strategies, previously used mainly by Democratic AGs during the Bush Administration, to push back on President Obama's policies. Moreover, this litigation illustrates how AGs have increasingly split along partisan lines to face off against one another in court. Here, as elsewhere, Republican and Democratic AGs formed opposing coalitions either challenging or supporting federal policy. Among other things, it serves as a reminder that when "the states" sue it really means that "the AGs" - all with partisan affiliations - are typically the ones bringing the lawsuits.

One important issue the Supreme Court's one-sentence decision left unresolved was the threshold issue of whether AGs had standing to challenge the Obama Administration's actions in the first place. This standing issue received a great deal of attention in both lower court cases, with both courts providing expansive standing for AGs to challenge federal immigration policy despite the federal government's traditionally exclusive role over this area. The District Court devoted a significant portion of its opinion to the issue, holding that the states had demonstrated concrete harm, that these harms were caused by the federal government's actions, and that the harms could be redressed by a favorable court decision (Texas v. United States, 86 F. Supp. 3d 591, 614-644 [S.D. Tex. 2015]).

This was an important holding, not only because it allowed the plaintiff AGs to proceed to the merits but because it suggested that AGs could rely upon an expansive interpretation of "concrete" state harms in order to get into court. The Fifth Circuit's decision was even friendlier 
to state standing claims. Relying more heavily on this ground than did the District Court, the Fifth Circuit held that the states were entitled to "special solicitude" in the court's standing analysis. This doctrine had been part of the Supreme Court's Massachusetts v. EPA decision in 2007, which held that a coalition of AGs had standing to challenge the EPA's refusal to regulate greenhouse gases. According to the Massachusetts majority, the states "are not normal litigants for the purposes of invoking federal jurisdiction," since they have "quasi-sovereign" interests in their territory that can be affected by federal action. Because states surrendered some of their sovereign prerogatives to the federal government when they joined the union - Massachusetts cannot invade New York to force the latter to reduce pollution drifting into the former - states should have additional ability to protect their interests in the courts. The Fifth Circuit applied this rationale to immigration, holding that "DAPA affects the states' 'quasi-sovereign' interests by imposing substantial pressure on them to change their laws, which provide for issuing driver's licenses to some aliens and subsidizing those licenses" (Texas v. United States, 809 F.3d 134, 153 [5th Cir. 2015]).

Since the Court's decision in Massachusetts v. EPA, it has not been clear just how far the "special solitude" rule would stretch. However, the Fifth Circuit's decision illustrates that the special solicitude standard is alive and well, providing an additional legal avenue for AGs to challenge federal policy. In addition to relying on this standard in Texas v. U.S., Republican AGs used this "special solicitude" standard to argue that they had standing to challenge the Affordable Care Act, for instance (Virginia v. Sebelius, 702 F. Supp. 2d 598, 606 n5 [E.D. Va. 2010]). More recently, Democratic AGs relied upon the special solitude standard to challenge President Trump's immigration orders. ${ }^{12}$ In short, this standard has proven to be a source of considerable 
leverage for AGs to challenge federal policy - even in areas like immigration law that have traditionally been controlled by the federal government.

\section{The Expansion of AG Polarization: Climate Change and the AGs}

American environmental policy operates as a classic example of cooperative federalism. Under many key environmental statutes, including the Clean Air Act (CAA), states serve a primary role in implementing minimum pollution standards set by the federal government. This approach aims to both harness regulatory power on both levels of government and to reduce a potentially destructive "race to the bottom" in state environmental standard-setting (Engel 2015). While this cooperative model has prompted federal and state officials to work together to solve common concerns, it also opened the door for states to have greater say concerning the shape and extent of national regulatory policy. The structure of this "cooperative" regulatory regime provides opportunities for state officials to both work with and push back against federal approaches in this area.

AGs have taken advantage of this dynamic to emerge as major players in environmental policy over the past two presidential administrations. During the George W. Bush Administration, coalitions of mostly Democratic AGs frequently took the EPA to court to push back on what they viewed as the administration's lackadaisical approach to addressing emerging environmental issues. The AGs' most important litigation campaigns concerned climate change, which aimed to prod the federal government to take more aggressive steps to address greenhouse gases in the absence of congressional or federal executive action. In 2007, a coalition of twelve AGs, led by Massachusetts AG Tom Reilly, scored a major Supreme Court victory in the aforementioned Massachusetts v. EPA. This case established both that the EPA could regulate 
greenhouse gases under the Clean Air Act (CAA) and rejected the reasons the EPA had offered to explain why it had refused to regulate them. This, in turn, provided the legal authority for the EPA to start addressing climate change through the regulatory process (Nolette 2015a).

The AGs' involvement in this area intensified as the Obama Administration used this legal authority to take numerous steps to regulate greenhouse gases. I focus on two aspects of the AGs' involvement here. The first is a major challenge to a central Obama climate change initiative, the Clean Power Plan. The main case, West Virginia v. EPA, is emblematic of the partisan trends and coalitions among AGs that have become entrenched during the Obama years. Similar to the immigration case, this litigation has spurred opposing coalitions of AGs to take the side of the federal government against their fellow states.

However, it was not just Republican AGs taking the initiative against Obama and Democratic AG allies. Liberal AGs sought to use a different strategy - modelled in some ways on the tobacco litigation of the late 1990 s - to address the issue. Starting in early 2016 , a group of AGs launched a "AGs United for Clean Power" initiative involving investigations into energy firms. Of particular importance was an investigation into ExxonMobil's activities launched by several AGs in March 2016, after several AGs claimed the company engaged in actionable fraud by suppressing evidence of its contribution to climate change. This investigation, and the reaction to it from opposing AGs and their allies in Congress and the private sector, highlights the deepening relationships between AGs and those inside and outside of government.

\section{The Clean Power Plan and Subsequent AG Challenges}

Similar to immigration policy, much of the Obama-era federal action pertaining to climate change policy was spurred not by Congress but by executive action. Beginning with EPA 
rulemaking establishing that greenhouse gases endangered human health or welfare, a key finding that set the stage for invoking many of the CAA's provisions, the Obama Administration's EPA subsequently issued regulations pertaining to greenhouse gas emissions from motor vehicles. ${ }^{13}$ The EPA also sought to expand regulation of power plants and other major greenhouse gas emitters, taking a series of aggressive regulatory steps in the absence of new congressional legislation on the subject. The centerpiece of these efforts was the Clean Power Plan (CPP) announced in June 2014, which consisted of a series of rules requiring existing electric generating utilities to reduce emissions levels to 32 percent below their 2005 levels in the next fifteen years. President Obama suggested that the CPP was "the single most important step America has ever taken in the fight against global climate change" and a crucial part of the administration's attempts to force power plants to shift from coal to wind and solar power (White House 2015).

Just days after Obama's announcement of the CPP, Ohio coal mining firm Murray Energy filed a petition in the D.C. Circuit calling for the court to declare the rules invalid. ${ }^{14} \mathrm{~A}$ week later, West Virginia AG Patrick Morrissey and eleven other AGs filed an amicus curiae brief supporting Murray Energy's positon. ${ }^{15}$ What was particularly unusual about this challenge was that it was launched before the regulations were even finalized in the Federal Register, typically the stage at which legal challenges to new regulations begin. According to the AGs, this early challenge was justified because the CPP's tight deadlines for state compliance with federal mandates meant that the states would have significant expenditures immediately.

Shortly after this challenge, both the AGs and Murray Energy filed additional complaints in the D.C. Circuit challenging a 2010 settlement agreement signed by the EPA that had set the stage for EPA regulation of existing power plants. ${ }^{16}$ The settlement agreement had resolved a 
lawsuit initiated in 2006 by a coalition of Democratic AGs and environmental groups seeking to force the EPA to regulate greenhouse gases emitted from power plants. Under the terms of the settlement, the EPA agreed to issue new regulations under §111(d) of the CAA, which pertains the state-implemented pollution standards for existing power plants. ${ }^{17}$ The problem, according to the West Virginia-led AG coalition, was that the CAA did not allow regulation under this section if the same power plants were already regulated under $\S 112$ of the CAA, which governs hazardous air pollutants standards. They claimed the EPA was trying to circumvent this limitation by committing the agency to regulate under $§ 111(d)$ through a binding legal agreement with collusive AGs and environmental groups.

The D.C. Circuit eventually sided against the West Virginia coalition, ruling that it did not have the authority to review mere proposed rules and rejecting the challenge to the 2011 settlement agreement on the grounds that the plaintiffs lacked standing to challenge it (In re Murray Energy Corp., Nos. 14-1112 et al. [D.C. Cir. June 9, 2015]). However, this concluded only the first wave of litigation over the CPP. On the same day that the EPA finalized the CPP in October 2015, a coalition of twenty-four AGs and state agencies filed a motion to stay the rules (West Virginia, et al. v. EPA, No. 15-1363 [D.C. Cir., filed October 23, 2015]). Other AGs filed separate but closely linked challenges, as did a large number of business associations, labor groups, and utilities. The basic argument was that the states and other groups would suffer "immediate and irreparable harm" due to the tight timeline demanded by the EPA for states to implement the new rules. The plaintiffs argued that they were likely to prevail on the merits for the same statutory and constitutional reasons as the parties had raised in the earlier litigation prior to the EPA's finalized rule. 
The litigation generated numerous filings from states either challenging or supporting the EPA, as indicated in Table 3. A counter-coalition of nineteen Democratic AGs, led by New York AG Eric Schneiderman, intervened to support the EPA's position. Several environmental and industry groups also joined the EPA's position. Members of Congress became involved in the litigation as well, filing amicus briefs on highly polarized lines either supporting or opposing the challenge. ${ }^{18}$

[Table 3 about here]

In a brief order in January 2016, the D.C. Circuit denied the request to stay the CPP. However, the AGs and allied groups took the unusual step of asking the Supreme Court for a stay, despite the fact that the lower court had not yet addressed the merits of the case. This unusual request paid off. By a five-four vote on February 9, 2016 - only four days before Justice Scalia died - the Supreme Court issued a stay of the program until the lower court decided the merits. This marked the first time that the Court granted a request to halt a regulation before a lower court had even reviewed it (Liptak and Davenport 2016).

The Supreme Court's stay meant that the program could not be implemented until the D.C. Circuit, and eventually the Supreme Court, resolves the merits of the dispute. The D.C. Circuit held over seven hours of oral arguments in September 2016, and a decision on the merits is (as of April 2017) pending. Most importantly, however, the Republican sweep in the 2016 elections offered the Trump Administration a chance to reverse the CPP through executive and legislative actions regardless of future judicial decisions. Indeed, in March 2017 President Trump issued an executive order directing the rollback of the CPP, and the Scott Pruitt-led EPA asked 
the D.C. Circuit to delay a ruling in the case until the agency had an opportunity to respond to Trump's executive order (Rodriguez 2017). Given that the CPP looks likely to be reversed during Trump's presidency, the West Virginia-led AGs' strategy of delaying the plan until the subsequent administration appears to have been successful.

\section{AGs United for Clean Power}

The West Virginia v. EPA litigation was probably the most important of the AG challenges to various EPA regulations during the Obama Administration. Yet it was not only AG opponents of expanded climate change regulation who have acted. AGs seeking greater regulatory steps to address climate change have employed new strategies to expand regulation by directly targeting the utilities the AGs allege have contributed climate change.

The key effort began in March 2016 when a coalition of sixteen AGs, along with several local officials and former Vice President Al Gore, announced the formation of "AGs United for Clean Power." The stated purpose of this group, which consisted mainly of the same Democratic members of the AG coalition that had intervened to support the EPA in West Virginia v. EPA, was to determine whether the company lied to investors and the public about the threat to climate change and the company's contributions to it. Among other things, the group members sought to focus on Exxon Mobil's funding of outside groups that challenged climate science and whether statements made to investors about climate risks conflicted with the company's own internal studies (Schwartz 2016a).

The new coalition was the culmination of a four-year coordinated strategy by environmental organizations to hold "Big Oil" legally accountable for climate change denial (McKenna 2016). Starting in 2012, leading members from these groups had strategized about 
how to best fight the energy industry in the courts in order to procure internal documents and spur attention to the industry's political strategies. These groups saw promise in teaming with AGs, especially given the wide range of investigatory powers AGs have under federal and state laws. The strategy began to come to fruition in November 2015, when New York AG Eric Schneiderman issued a subpoena to ExxonMobil demanding four decades of documents relating to internal company communications on climate change. Following this action, members of the environmental organizations met with AGs early in 2016 to discuss legal strategies going forward - a meeting that was followed shortly after by the announcement of the AGs United for Clean Power.

This coalition's legal strategy aimed to follow the pattern of the AGs' tobacco litigation in the late 1990s, a point made explicitly by Gore during the press conference announcing the group. The tobacco litigation, which eventually involved all of the nation's AGs, featured AGs using their significant investigative powers to force the industry to divulge information about what the company had known about the health risks of tobacco. Among the millions of documents obtained during the investigation were several that implied that the industry knew more about the dangers of smoking than the companies were admitting publically. These, in turn, provided leverage for the AGs to settle their claims with the largest tobacco manufacturers as part of a \$206 billion global settlement in 1998 that remains the largest civil settlement in American history. In addition to the money, the settlement contained several regulatory provisions essentially restructuring the entire industry and limiting tobacco advertising and lobbying (Derthick 2012).

Similarly, the AGs part of the group intended to uncover similar "smoking guns" that could be used to eventually force ExxonMobil and other energy companies to enter regulatory 
settlements. "It's too early to say what we're going to find," Schneiderman said during the announcement of the coalition, but "we intend to work as aggressively as possible" (Schwartz 2016a). The effort would include bringing to bear several laws granting AGs wide investigatory powers, including the Racketeer Influenced and Corrupt Organizations Act (RICO) and several state consumer protection and deceptive business and trade practices acts. These same statutes had played a major role in the tobacco litigation as well. The AGs argued that this effort was necessary in light of the federal government's failure to do more to address climate change. As Rhode Island AG Peter Kilmartin put it, "if Washington is not going to step up and recognize the crisis and find meaningful solutions, then it will be up to the states to do so" (New York Attorney General 2016).

While most of the AGs attending the meeting did not reveal whether they had started any investigations, three AGs did specify that they had opened their own investigations - California AG Kamala Harris, Massachusetts AG Maura Healey, and U.S. Virgin Islands AG Claude Walker. Walker's investigation was particularly wide-ranging, as he issued subpoenas not only to ExxonMobil but also to conservative organizations looking for evidence that the company teamed up with ideological groups to oppose climate change (Schwartz 2016c).

The announcement of the AGs United for Clean Power group and its intentions to conduct wider probes into the energy industry sparked a considerable backlash. ExxonMobil filed suit against Healey and Walker, arguing that the AGs' subpoenas violated due process as well as the company's free speech rights (Exxon Mobil v. Walker, No. 017-284890-16 [Dist. Ct. Tarrant County, Tex., April 13, 2016]; Exxon Mobil v. Healey, No. 4:16-cv-00469-A [N.D. Tex. June 15, 2016]). Soon after, eleven Republican AGs filed an amicus brief supporting ExxonMobil's attempt to enjoin their fellow AG's investigation into the company. The brief 
accused their colleague of "using law enforcement authority to resolve a public policy debate" and argued that Massachusetts' actions represented "an abuse of its subpoena powers."19

Members of Congress also pushed back on the states' investigations. In May 2016, the Republican members of the U.S. House's Committee on Science, Space, and Technology sent a letter to Schneiderman informing him of the committee's intention to investigate the AGs' "coordinated attempt to deprive companies, nonprofit organizations, and scientists of their First Amendment rights and ability to fund and conduct scientific research free from intimidation and threats of prosecution." The committee subpoenaed numerous documents from the AGs and several environmental groups, including any communications the AG members had with the environmental advocacy groups, other AGs, and representatives of federal agencies. ${ }^{20}$ This marked the first time that a House committee had subpoenaed a state AG (Schwartz 2016d).

The AGs refused to comply with the congressional subpoenas, calling the request "a dangerous overreach by the Committee and an affront to states' rights" (Hasemyer 2016). Nevertheless, the legal pushback from ExxonMobil and its AG amici led to both Walker and Healey withdrawing their subpoenas. As of this writing, the AGs' investigations remain active, though it remains unclear to what extent courts will allow the investigations to proceed.

\section{Lessons of the Climate Change Battles}

Regardless of the ultimate result of the CPP challenges and the AG investigations of ExxonMobil, they both highlight several key aspects of AG activism during the latter years of the Obama Administration. For one, AGs remain as committed as ever to the creative use of their expansive powers - which operate largely independently from other state officials - to achieve national public policy goals. This now firmly entrenched nationalized activism has meant that 
AG strategizing about potential legal challenges is ongoing and anticipatory, rather than ad hoc and reactive. Republican AGs were already in conversations about how to challenge the CPP before even the proposed rules were announced, allowing near-immediate challenges to administration policies. The plaintiff AG coalition employed something of a "kitchen sink" approach of using various substantive and procedural arguments to delay the rules, including taking the unusual step of challenging the EPA's new rules at every stage before they even became final. Likewise, the AGs United for Clean Power initiative has relied upon new arguments based on expansive definitions of "fraud" in state investigations to advance broader nationally-focused goals on climate change.

Unlike many previous federalism disputes in American history that have primarily involved regional divisions, it is partisan divisions that have been most prominent in these disputes. As with the West Virginia v. EPA litigation, Democratic and Republican AGs have taken opposing positions on climate change mirroring the broader partisan coalitions of which they are a part. In this way, the Obama-era legal battles over federal policies affecting federalism simply cannot be characterized as involving "the states versus the national government." Instead, these battles involve sharp conflicts among the states themselves, with some challenging and others defending the exercise of federal power. This partisanship is also apparent in the remarkable conflict over the past year involving the investigations of ExxonMobil, in which AGs partnered with the target of the investigation to argue against their fellow AGs' exercise of prosecutorial power.

The climate change battles also provide a good example of AG alliances with likeminded outside groups. The idea of employing RICO and state consumer protection statutes against energy firms originated with environmental interest groups that later worked with the 
Democratic AGs implementing the strategy in the ExxonMobil investigations. This builds upon relationships forged between AGs and environmental group allies during the Bush and Obama Administrations, which included Massachusetts v. EPA and various subsequent efforts to force the federal government to address climate change. Meanwhile, Republican AGs worked with industry groups to defend against stricter pollution regulations, joining with ExxonMobil against their fellow AGs' investigations and coordinating legal strategies with Murray Energy in the parallel CPP challenges.

Throughout these battles, both sides have used evidence of these AG-outside group collaborations as a basis to attack the opposing side. The collaborations between environmental groups and AGs sparked the congressional investigation into AGs United for Clean Power. Similarly, Republican AGs pointed to "collusive" settlements between liberal AGs, environmental groups, and the EPA as evidence of a "sue-and-settle" strategy meant to operate as an end-run around Congress and the regulatory process (Monies 2013). Democratic AGs demanded that Republican AGs reveal their connections with industry groups during the West Virginia v. EPA litigation, and pointed out that Murray Energy had donated $\$ 250,000$ to the Republican Attorneys General Association shortly before the litigation began (Dlouhy 2016).

The increasing partisanship among AGs has occurred amidst the broader polarization throughout the Obama years. AG challenges to Obama Administration policies represented an opportunity for a broader national Republican coalition to stop regulatory initiatives - something the Republican Congress could not accomplish legislatively because of President Obama's veto power. In much the same way, Democratic AG-led initiatives such as the AGs United for Clean Power were attempts to advance the goals of a broader partisan coalition without the necessity of involving Congress. 


\section{COOPERATION AND COLLABORATION IN AG ACTIVITY}

As important as these deepening partisan and ideological trends have been, AGs have continued to find common ground in much of their work. For one, Democratic and Republican AGs continue to work closely on criminal law issues, frequently appearing on bipartisan amicus briefs in federal court (Nolette 2014). Additionally, AGs have continued bipartisan enforcement efforts to fight alleged corporate fraud affecting multiple states - efforts frequently resulting in multistate settlements involving all or nearly all the nation's AGs (Yelkin 2007). Particularly important have been a series of multistate settlements with pharmaceutical companies targeting alleged fraud that have served to reform the industry's drug pricing and advertising nationwide (Nolette 2015b). Additionally, the federal government has sought more integrated federal-state enforcement efforts to achieve shared priorities, particularly concerning criminal law enforcement and anti-fraud initiatives. AGs have been the beneficiaries of increased enforcement capabilities and federal funding dating to the Crime Control and Safe Streets Act of 1968 and establishment of the National Association of Medicaid Fraud Control Units in 1978. Information sharing between the Department of Justice, other federal enforcement agencies, and the AGs has been a feature of cooperative enforcement efforts for decades.

Nevertheless, the AGs' relationship with federal enforcement agencies was frequently

rocky during the George W. Bush years. Agencies such as the Office of the Comptroller of the Currency sought to preempt AGs' role in corporate investigations, federal funding for state enforcement efforts faced cuts, and previously active federal-state working groups received lessened priority (National Association of Attorneys General 2009). As soon as Obama entered office, the National Association of Attorneys General urged the administration to establish a 
stronger relationship between the federal DOJ and state AGs (National Association of Attorneys General 2009).

\section{Recent Trends Towards Greater Cooperation in AG Activities}

The Obama Administration responded by expanding cooperative state-federal enforcement efforts in several ways. Several of the earliest major Obama legislative initiatives, including the American Recovery and Reinvestment Act as well as the Dodd-Frank Wall Street Reform and Consumer Protection Act, deputized AGs to enforce new federal laws. Federal funding for AG enforcement efforts, such as through Byrne Justice Assistance Grants, expanded dramatically in the American Recovery and Reinvestment Act of 2009 (McKay 2009). The Department of Justice and other key federal enforcement agencies drew heavily from the ranks of state-level enforcement personnel, likely contributing to the state-friendly attitude within these federal agencies.

The improved federal-state relationships were perhaps most apparent with the proliferation of multiagency task forces and working groups involving federal and state law enforcement personnel working together to address similar problems. Across a range of enforcement issues - from payday lending, to antitrust enforcement, to mortgage fraud - these initiatives have made AGs crucial partners in advancing national enforcement priorities.

The central effort was the Financial Fraud Enforcement Task Force established by President Obama's executive order in November 2009. The Task Force aimed "to wage aggressive and coordinated investigations and prosecutions of financial frauds and maximize the ability both to recover the proceeds of these frauds and obtain just and effective punishment of those who commit them" (Financial Fraud Enforcement Task Force n.d.). Since its creation, 
several interagency working groups have been housed under the broader Task Force, including groups pertaining to loan fraud, securities and commodity fraud, and financial institution fraud. In addition to the Financial Fraud Enforcement Task Force, the Department of Justice worked closely with AGs on various additional task forces ranging from intellectual property issues to antitrust enforcement. Throughout the past several years, the AGs' involvement in these collaborative efforts has been largely bipartisan.

The multiagency taskforce activity has resulted in considerable enforcement activity. In some cases, the close cooperation and information-sharing among federal-state enforcers has resulted in several separate but closely related settlements with individual targeted firms. For example, the DOJ and AGs worked together to investigate government claims that Volkswagen cheated emissions tests and deceived consumers, which ultimately resulted in closely linked federal and state settlements with the company in June 2016 (U.S. Department of Justice 2016). In others, these efforts have resulted in a single federal-state settlement with the corporate targets of the investigations. The Financial Fraud Enforcement Task Force, for example, concluded a \$26 billion joint federal-state settlement in 2012 between several federal agencies, forty-nine AGs, and the five largest mortgage servicers in the country. In addition to the monetary provisions, the settlement contained several new regulatory code-of-conduct provisions requiring substantial changes to how the servicers do business. These provisions achieved regulatory goals without congressional action or proceeding through the typical regulatory process (U.S. Department of Justice 2012).

The AGs' close and largely bipartisan cooperation with the Obama Administration's enforcement efforts contrasts with the simultaneous and contentious AG pushback on numerous Obama Administration initiatives. I now turn to a case study that helps illustrate the cooperative 
side of the relationship: coordinated efforts to investigate the for-profit higher education industry. While just one of many similarly collaborative federal-state efforts, I focus on the forprofit education sector in part because these efforts have received less attention than the more high-profile efforts involving the financial sector after the Great Recession and because of the sheer effect that this litigation had on a major national industry. What had been a rapidly growing sector was, after AG investigations and Obama Administration actions, a much diminished and besieged one. Additionally, like the tobacco litigation and mortgage litigation mentioned earlier, this litigation illustrates that AGs have increasingly taken advantage of not only federalism as a veto point to block policy, but as an opportunity point advancing policy goals in the absence of new congressional legislation. In this case, AGs partnered with likeminded members of the federal executive branch to build on each other's efforts and place additional regulatory pressure on the industry.

\section{Cooperative Federalism in Action: Oversight of the For-Profit Higher Education Industry}

Most colleges and universities in the United States have historically been non-profit institutions. The for-profit model grew rapidly beginning in the 1970s, however, following an amendment to the Higher Education Act allowing for-profit institutions access to federal funds (including grants and student loans). Institutions such as the University of Phoenix, DeVry University, ITT Tech, and several others gained thousands of students during the rapid growth of the industry in the decades since. By 2007, the Department of Education stated that the number of for-profit colleges and universities has grown to over 1,000 institutions, and in 2009 enrollment in these institutions reached its peak (Lederman 2010). The University of Phoenix, claiming some 300,000 students nationwide, became the largest private university in America. 
Despite this rapid growth, however, the high percentage of student defaults and low graduation rates led to increased federal scrutiny of the industry as early as the 1980s. But it was a pair of key federal government reports that provided additional attention to the industry and escalated the industry's legal problems. A 2009 report by the Government Accountability Office (GAO) suggested that students at for-profit schools had particularly low graduation rates yet were left with very high debt levels (U.S. Government Accountability Office 2009). Another GAO report the following year found evidence of deceptive tactics and fraud at several for-profit colleges. The report, which followed an undercover sting involving investigators posing as students interested in enrolling in for-profit colleges, detailed how several colleges encouraged students to provide false information on student loan applications. The report also found that school officials at fifteen for-profit institutions had also provided misleading information about the programs' costs and the employment prospects for students graduating from the programs (U.S. Government Accountability Office 2010).

Significant subsequent revisions to the GAO report softened several of its harshest evaluations of the industry, leading to criticism of the GAO by Republican members of Congress and to a lawsuit by a for-profit education industry group (Weinberger 2011). Nevertheless, the report sparked additional oversight of the industry from several quarters. The GAO's report was followed up by a two-year investigation led by Senator Tom Harkin (D-IA) that highlighted various problems in the industry (U.S. Senate HELP Committee 2012). Meanwhile, the Department of Education proposed new regulations, referred to as "gainful employment" rules, which would cut off federal funding to for-profit colleges whose graduates did not earn enough to repay their loans (Epstein 2010). 


\section{AGs' Involvement and the Taskforce on For-Profit Education}

In addition to sparking additional activity from congressional committees and federal agencies, the GAO's findings sparked a series of new investigations, including several led by AGs. Several individual AGs had been involved in investigations of for-profit colleges as early as the mid-2000s, spurred in part by the AGs' concerns that federal agencies were not making progress in developing stronger oversight of the industry (Dillon 2007). With the GAO report and increasing federal activity in this area, the AGs' investigations quickly expanded. The Florida AG's office opened up a major investigation of eight for-profit colleges shortly after the release of the GAO report, and the New York Attorney General started investigating institutions that had been found by GAO to have deceptive recruiting tactics. Other AGs soon followed with their own independent investigations, several of which led to multi-million dollar settlements from 2011 to 2013.

The major AG probe of the industry began in January 2014, when a dozen AGs collectively served a series of subpoenas and civil investigative demands on four major for-profit schools. These actions were part of a larger bipartisan coalition of thirty-two AGs investigating the industry, led by Kentucky AG Jack Conway. The investigation was predicated on the theory that the for-profit schools had violated several state consumer protection statutes through the types of behavior uncovered by the GAO and the Harkin probe. These investigations occurred alongside enforcement actions by the newly-created Consumer Financial Protection Bureau (CFPB) and the Securities and Exchange Commission against the same schools in the AG investigations. At the time, Conway suggested that he expected AG collaboration with federal agencies to increase in the coming months (Armor and Zibel 2014). 
This collaboration came to fruition in October of 2014, when the Department of Education announced the creation of a new interagency taskforce on for-profit education. The taskforce, which included as members several federal agencies as well as AGs, sought to formalize a working group that had (among other things) launched the investigations earlier in the year. According to the DOE, the task force's purpose would allow members to "leverage their resources and expertise to assist one another, thereby making the best use of scarce resources and better protecting the interests of students and taxpayers" (U.S. Department of Education 2014). This collaboration strengthened further in 2016 when the Federal Trade Commission stated that it would take additional consumer protection enforcement measures alongside AGs.

Since its creation, the interagency taskforce has taken various actions against several forprofit schools and in a relatively short time placed the entire industry on life support. Some of the actions occurred independently but parallel to one another, with federal agencies and AGs sharing information leading to subpoenas and subsequent lawsuits against the same institutions. Other actions have resulted in single, coordinated federal-state settlements conducted in a similar fashion to the settlements achieved by the Financial Fraud Enforcement Task Force.

For example, a November 2015 settlement with Education Management Corporation (EDMC) involving the federal government and thirty-nine AGs resolved a variety of claims against the company. These claims included state consumer protection claims as well as under the federal False Claims Act, which allows the government to recover funds from private entities who used fraud to obtain public money. The settlement included a $\$ 95$ million fine paid to the government and \$102 million worth of debt relief to affected students, but the settlement's most important contributions were in its conduct terms. The terms, which read like agency regulations, 
required the company to provide students additional disclosures, orientation programs, and opportunities to withdraw from programs free of charge. It also created a new industry monitor that would oversee the company's compliance with the settlement terms (U.S. Department of Justice 2015). While only applicable to EDMC, the taskforce members stated that they hoped these terms would serve as a code of conduct for other members of the industry - including the many that remained potential targets of the AGs and the broader taskforce.

\section{Interagency Enforcement and the Cooperative Extension of the Regulatory State}

The progression of coordinated legal attacks on the for-profit higher education industry illustrates a different and more cooperative version of AG activism during the Obama Administration. In this case, investigations by the federal GAO and Congress provided momentum for AGs to pursue state-level probes themselves, which in turn helped feed further investigations by federal enforcement agencies. Eventually, the relationships between the federal government (the DOJ, CFPB, and other agencies) and the AGs strengthened as their investigations and settlements became explicitly cooperative.

As with other interagency task forces, particularly the Financial Fraud Enforcement Task Force, the resolution of investigations sought to achieve policy and regulatory changes in an industry in the face of perceived congressional inaction. Advocates for industry reform pressed Congress to curb alleged abuses, particularly after the initial GAO report, but little legislative action was forthcoming. The response was to employ enforcement actions to achieve quasiregulatory settlements that sought to establish the new codes of conduct Congress would not.

This cooperative activity has tended to attract more bipartisan support. Most of the nation's AGs, both Democrats and Republicans, were involved in the federal/state investigations 
into the for-profit education sector. That said, these efforts have received some criticism for potentially exceeding executive power at the expense of Congress. As the interagency taskforce on for-profit education became more active, for example, several Republican U.S. Senators sent a letter to the DOE Secretary skeptically probing the purposes of and statutory authority for the task force.$^{21}$ The taskforce's formation, after all, occurred amidst failures to enact the Proprietary Education Oversight Coordination Improvement Act (also supported by many AGs), which would have explicitly allowed interagency oversight of the for-profit education industry. As "informal" coordination, by contrast, the taskforce did not have similar legislative authority. Nevertheless, the initiative continued to generate bipartisan enforcement actions throughout the remainder of the Obama presidency.

As with many other policy areas, it remains to be seen how the Trump Administration will handle allegations of fraud by for-profit educational institutions. Many observers believed a significant policy shift would occur, particularly given that Trump's own for-profit university was the target of an AG investigation that settled for \$25 million shortly after the 2016 election, and his Education Secretary, Betsy DeVos, has been an advocate for private educational institutions. Yet the Trump Administration also defended stricter Obama-era regulations in court against an industry challenge, suggesting that the administration will abide by at least some of the new regulatory accomplishments during the previous administration (Bloomberg News 2017).

Regardless of what the federal government does, the cooperation among AGs on this issue continues as well. Several of the AGs involved in the Obama-era for-profit education probes vowed to continue their investigations with or without the federal government. Just days after President Trump entered office, for example, AGs sought to intervene in a federal case 
against a major for-profit college accreditor. The timing was not coincidental; in the words of one education policy observer, "the intervention serves as a form of insurance" in case the Trump Administration attempted to drop the lawsuit (Waldman 2017).

\section{CONCLUSION}

Both the conflictual and cooperative elements of AG activity during Obama's presidency contributed to the entrenchment of AGs' roles in national policy. Republican AGs established mechanisms of coordination amongst themselves to find new ways of challenging Obama's policies. This in turn spurred the creation of Democratic AG coalitions that supported the administration and sought innovative ways to use their powers of investigation to achieve liberal policy goals. The AGs' more cooperative relationships with the federal government also served to bolster AG power. The Obama Administration invited AGs to work with executive officials as part of several interagency taskforces, in the process forging strong and continuous relationships between federal and state law enforcement. In addition to both sides generating and sharing information about potential enforcement actions, AGs and federal agencies built on the each other's efforts to place additional pressure on national industries to change their practices. Negotiated settlements between federal agencies, AGs, and leading members of industry established new regulatory baselines and codes of conduct across national industries - even as congressional efforts to address alleged abuses in economic sectors such as mortgage lending and for-profit higher education stalled.

With a Trump Administration pursuing very different goals alongside unified Republican governance on the federal level, it remains to be seen how the relationships between AGs and the federal government will evolve. However, several of the trends emerging during the Obama 
years appear likely to continue. Indeed, the AGs' entrenched role as a veto point frustrating administration policies paid dividends for Democratic AGs even in the early weeks of Trump's presidency. Very shortly after Trump announced new immigration limits via executive order, several AGs successfully enjoined the actions in court (Associated Press 2017). Furthermore, much like their Republican counterparts during the Obama years, Democratic AGs are preparing to battle the Trump Administration on a variety of anticipated policy changes (Burns 2017). As Xavier Becerra, who relinquished a top leadership position in Congress for the chance to become California's AG, remarked in reference to challenging President Trump in court: "I see it as a team sport" (Hart 2017).

AGs are likely to continue seeking additional ways of expanding their authority to achieve their policy goals. Democratic AGs partnered with legal actors in increasingly Democratic cities to challenge Trump's immigration orders, and have vowed to partner with them again if the president acts to cut federal funding as retaliation for localities refusing to enforce federal immigration laws (The Economist 2017). AGs have also used the expansive interpretations of state standing developed in Republican challenges to Obama's policies to challenge Trump's executive orders. ${ }^{22}$ Meanwhile, one Democratic state legislature (Maryland) enacted legislation providing its Democratic AG expanded powers to circumvent the Republican governor in order to sue Trump - the first time Maryland had expanded its AG's power since 1864 (Cox 2017).

This sort of ideological conflict among the AGs and other institutions is likely to continue and perhaps strengthen further, reflecting both the trends among AGs and the broader American political system. The last year of the Obama presidency, for example, witnessed an unprecedented effort by Republican AGs - along with fellow Republicans in Congress - to 
challenge Democratic AGs' authority to conduct their own in-state (but coordinated) investigations of ExxonMobil. While individual AGs have occasionally criticized allegedly overzealous investigations by AGs of the other party, AGs' active intervention in litigation opposing their fellow AGs' state-level investigations is a new development.

The sharpening polarization of AG activism has also been reflected in partisan conflicts between AGs and other state-level officials. During the Obama Administration, governors and AGs of the opposite party clashed frequently. Republican governors claimed the authority to represent the state in litigation challenging federal law when Democratic AGs refused to do so, over objections that the AG has the sole authority to represent the state in court (Baltz 2015). Several Democratic AGs took the unusual position of refusing to defend challenges to their own state's laws in the context of same-sex marriage and controversial transgender bathroom bills, spurring in-state Republicans to seek their own legal counsel to take up the defense (e.g., Blythe 2016). Even more recently, Republican Texas AG provided another example of intra-state conflict by joining lawsuits challenging policies adopted by Texas cities under Democratic control, and Maine's Democratic AG sued the Republican governor for violating the state's open meetings law (Formby 2016; Thistle 2016).

The emergence of new avenues of partisan conflict is due not only to the continuing polarization in American society generally, but is also a consequence of the strengthening collaborations between AGs and like-minded ideological allies outside of government. Several of the Republican-led challenges to Obama Administration policies received strategic and financial support from conservative and industry groups, and Democratic AGs have continued to coordinate with liberal groups on litigation strategies. Meanwhile, the respective Republican and Democratic AG Associations have become major lobbying targets, including by business entities 
subject to possible investigations and private class-action attorneys looking to partner with AGs on lawsuits (Lipton 2014).

While there are few signs that the polarized AG activism of the Obama years will disappear during the Trump presidency, it is unclear whether and how federal executives in the next administration will work cooperatively with AGs to address common concerns. The Obama Administration took particular care to include AGs in interagency enforcement taskforces, in part to strengthen the prospects that the regulatory provisions of global federal-state settlements would stick. However, the combination of unified Republican government and a more deregulatory outlook on the part of federal agencies during the Trump Administration may lessen the commitment to this form of cooperation as a method of industry oversight. Even so, AGs and the federal DOJ may find areas to work collaboratively on some enforcement issues, much as they did despite often testy relationships during the conservative George W. Bush Administration - including, importantly, on joint federal-state efforts to tackle issues of crime, drugs, and Medicaid fraud. During his first address to the National Association of Attorneys General, for example, Attorney General Jeff Sessions announced a new Task Force on Crime Reduction and Public Safety that would work collaboratively with AGs (U.S. Department of Justice 2017).

Regardless of how the balance of contention and cooperation among AGs and the federal government shapes up in the coming years, it is safe to say that AGs will not easily concede the considerable influence on the national stage that they have built up over the past two presidential administrations. President Trump, like Obama and Bush before him, will need to contend with the growing national activism of these important state-level officials. 


\section{REFERENCES}

Armor, Stephanie, and Alan Zibel. 2014. For Profit College Probe Expands. Wall Street Journal. January 13.

Associated Press. 2017. Hawaii Judge Extends Order Blocking Trump’s Travel Ban. March 29.

Baltz, Tripp. 2015. Clean Power Plan Divides Governors, Attorneys General. Bloomberg BNA. November 9.

Bloomberg News. 2017. Trump Defends Obama’s For-Profit College Crackdown. April 4.

Blythe, Anne. 2016. NC Attorney General Refuses to Defend State from HB2 Legal Challenge. The News \& Observer (Raleigh, NC). March 29. 
Bowling, Cynthia J., and J. Mitchell Pickerill. 2013. Fragmented Federalism: The State of American Federalism 2012-13. Publius: The Journal of Federalism 43(3): 315-346.

Bray, Samuel L. Forthcoming. Multiple Chancellors: Reforming the National Injunction. Harvard Law Review.

Burns, Alexandra. 2017. How Attorneys General Became Democrats' Bulwark Against Trump. New York Times. February 6.

Clayton, Cornell. 1994. Law Politics, and the New Federalism: State Attorneys General as National Policymakers. Review of Politics 56(3): 525-553.

Cox, Erin. 2017. Maryland Attorney General Frosh Awarded Expanded Power to Sue Trump Administration. Baltimore Sun. February 15.

Curriden, Mark. 1999. Republican AG Group Creates Friction; Stated Goal Is to Battle Trend of Making Policy via Litigation. Dallas Morning News. July 10.

Derthick, Martha. 2012. Up in Smoke: From Legislation to Litigation in Tobacco Politics. $3^{\text {rd }}$ ed. Washington, DC: CQ Press.

Dillon, Sam. 2007. In U.S. Absence, States Take Lead in Student Loan Cases. New York Times. April 24.

Dlouhy, Jennifer A. 2016. Battered Coal Companies Courted State AGs to Fight Climate Rules," Bloomberg, September 7.

Elmore, Charles. 2011. Lobbying Group Picks up Costs of Florida's Health-Care Challenge. Palm Beach Post (FL). February 19.

Engel, Kirsten H. 2015. EPA's Clean Power Plan: An Emerging New Cooperative Federalism? Publius: The Journal of Federalism 45(3): 452-474.

Epstein, Jennifer. 2010. Closer Look at “Gainful Employment.” Inside Higher Ed. July 26.

Financial Fraud Enforcement Task Force. N.d. About the Task Force. https://www.stopfraud.gov/about.html (last accessed November 12, 2016).

Formby, Brandon. 2016. AG Ken Paxton Asks to Jump into Austin Rental Fight. Texas Tribune. October 5.

Hart, Angela. 2017. Battling Trump is a "Team Sport," California's Attorney General Says. Sacramento Bee. March 27.

Hasemyer, David. 2016. State AGs and Groups Defy Lamar Smith's Subpoena Over Exxon Climate Probes. Inside Climate News, July 27. 
Iyengar, Shanto, and Sean J. Westwood. 2015. Fear and Loathing Across Party Lines: New Evidence on Group Polarization. American Journal of Political Science 59(3): 690-707.

Jarvis, Craig, and Anne Blythe. 2016. NC Will Defend Voter ID without Attorney General. The News \& Observer (Raleigh, N.C.). August 2.

Jordan, Soren, and Cynthia J. Bowling. 2017. Introduction: The State of Polarization in the States. State and Local Government Review. Online First.

Lederman, Doug. 2010. 3 Million and Counting. Inside Higher Ed. August 26.

Lemos, Margaret H., and Kevin M. Quinn. 2015. Litigating State Interests: Attorneys General as Amici. New York University Law Review 90: 1229-1268.

Liptak, Adam, and Coral Davenport. 2016. Supreme Court Deals Blow to Obama's Efforts to Regulate Coal Emissions. New York Times. February 9.

Lipton, Eric. 2014. Lobbyists, Bearings Gifts, Pursue Attorneys General. New York Times. October 28.

McKay, Jim. 2009. Stimulus Bill Revives Key Law Enforcement Grants. Government Technology, February 18.

McKenna, Phil. 2016. Activists Step Up Long-Running Campaign to Hold Oil Industry Accountable for Climate Damages. Inside Climate News, April 27.

Monies, Paul. 2013. Oklahoma Attorney General, 11 Others File Lawsuit Against EPA Over "Sue and Settle" Tactics. The Oklahoman, July 17.

National Association of Attorneys General. 2009. Interim Briefing Paper Prepared for PresidentElect Barack Obama Transition Team.

New York Attorney General. 2016. Press Release Announcing Coalition. March 29. http://www.ag.ny.gov/press-release/ag-schneiderman-former-vice-president-al-gore-andcoalition-attorneys-general-across (last accessed November 12, 2016).

Nolette, Paul. 2014. State Litigation during the Obama Administration: Diverging Agendas in an Era of Polarized Politics. Publius: The Journal of Federalism 44 (3): 451-474.

Nolette, Paul. 2015a. Federalism on Trial: State Attorneys General and National Policymaking in Contemporary America. Lawrence: University Press of Kansas, 2015.

Nolette, Paul. 2015b. Law Enforcement as Legal Mobilization: Reforming the Pharmaceutical Industry through Government Litigation. Law \& Social Inquiry 40(1): 123-151. 
Provost, Colin. 2003. State Attorneys General, Entrepreneurship, and Consumer Protection in the New Federalism. Publius: The Journal of Federalism 33 (2): 37-53

Provost, Colin. 2006. The Politics of Consumer Protection: Explaining State Attorney General Participation in Multi-State Lawsuits. Political Research Quarterly 59 (4): 609-618.

Rodriguez, Juan Carlos. 2017. EPA Asks DC Circ. To Put Off Ruling on Clean Power Plan. Law360. March 29.

Schwartz, John. 2016a. Exxon Mobil Climate Change Inquiry in New York Gains Allies. New York Times, March 29.

Schwartz, John. 2016b. State Officials Investigated Over Their Inquiry into Exxon Mobil's Climate Change Research. New York Times. May 19.

Schwartz, John. 2016c. Dueling Climate Change Inquiries as Lawmakers Take on State Officials. New York Times, May 20.

Schwartz, John. 2016d. Views Conflict on Exxon Mobil's Ties to Those Who Reject Climate Science, New York Times, September 15.

Shor, Boris, and Nolan McCarty. 2011. The Ideological Mapping of American Legislatures. American Political Science Review 105(3): 530-551.

The Economist. 2017. States and Cities Use Litigation to Fight Donald Trump's Immigration Orders. February 2.

Theriault, Sean. 2008. Party Polarization in Congress. New York: Cambridge University Press.

Thistle, Scott. 2016. Maine Attorney General to Sue LePage Administration Over Closed Commission Meeting, Portland Press Herald. July 7.

Thompson, Frank J., and Michael K. Gusmano. 2014. The Administrative Presidency and Fractious Federalism: The Case of Obamacare. Publius: The Journal of Federalism 44(3): 426450.

U.S. Department of Education. 2014. Obama Administration Announces Final Rules to Protect Students from Poor-Performing Career College Programs. October 30.

U.S. Department of Justice. 2012. Press Release. February 9.

https://www.justice.gov/opa/pr/federal-government-and-state-attorneys-general-reach-25-billionagreement-five-largest (last accessed November 12, 2016).

U.S. Department of Justice. 2015. For Profit College Company to Pay \$95.5 Million. November 16. 
U.S. Department of Justice. 2016. Press Release. June 28.

https://www.justice.gov/opa/pr/volkswagen-spend-147-billion-settle-allegations-cheatingemissions-tests-and-deceiving (last accessed November 12, 2016).

U.S. Department of Justice. 2017. Attorney General Jeff Sessions Delivers Remarks at National Association of Attorneys General Annual Winter Meeting. February 28.

U.S. Government Accountability Office. 2009. Proprietary Schools. Report to the Chairman, U.S. House Subcommittee on Higher Education. August.

U.S. Government Accountability Office. 2010. For Profit Colleges. Before the U.S. Senate Committee on Health, Education, Labor, and Pensions. August 4.

U.S. Senate HELP Committee. 2012. For Profit Higher Education: The Failure to Safeguard the Federal Investment and Ensure Student Success. July 30.

Waldman, Annie. 2017. States Move to Intervene in Federal Case on For-Profit College Watchdog. ProPublica. January 25.

Weinberger, Evan. 2011. For Profit Colleges Sue Over GAO Fraud Claims. Law360. February 3.

White House. 2015. Remarks by the President Announcing the Clean Power Plan. August 3, 2015. https://www.whitehouse.gov/the-press-office/2015/08/03/remarks-president-announcingclean-power-plan (last accessed November 12, 2016).

Wittes, Benjamin, and Pietro S. Nivola, eds. 2015. What Would Madison Do? The Father of the Constitution Meets Modern American Politics. Washington, DC: Brookings Institution Press.

Wong, Kenneth K. 2015. Federal ESEA Waivers as Reform Leverage: Politics and Variation in State Implementation. Publius: The Journal of Federalism 45(3): 405-426.

Yelkin, Kimberly A. 2007. States Target Medicaid Fraud in the Pharmaceutical Industry, Federation of Regulatory Counsel Journal 18 (Fall), www.oldforc.org/public/articles/285.pdf.

\footnotetext{
${ }^{1}$ Letter from 13 Attorneys General to Speaker Nancy Pelosi and Majority Leader Harry Reid, December 30, 2009, http://thehill.com/blogs/blog-briefing-room/news/73975-state-ags-request-reid-pelosi-drop-nebraska-medicaidfunds-from-health-bill.

${ }^{2}$ Complaint, Florida v. Health and Human Services, No. 3:10-cv-91 (N.D. Fla., filed March 23, 2010).

${ }^{3}$ For example, six AGs brought separate lawsuits in the mid-1990s alleging that the federal government had failed to control illegal immigration and thus harmed the states. Not only was this action not coordinated among the AGs, but it involved both Democratic and Republican AGs. See Texas v. United States, 106 F.3d 661, 664 (5th Cir. 1997). Other challenges during the 1990s followed a similar pattern.

${ }^{4}$ Republicans gained six seats in the 2010 elections, leading to a near even partisan balance in AG offices for the first time in decades.

${ }^{5}$ Brief of the States of Oregon, et al., Florida v. HHS, Nos. 11-11021-HH and 11-11067-HH (11th Cir., filed April $8,2011)$

${ }^{6}$ Complaint, Texas v. United States, No. 1:14-cv-254 (S.D. Tex.., filed December 9, 2014), 23-26.
} 
${ }^{7}$ Complaint, Texas v. United States, No. 1:14-cv-254 (S.D. Tex.., filed December 9, 2014), 27-28.

${ }^{8}$ Complaint, Texas v. United States, No. 1:14-cv-254 (S.D. Tex.., filed December 9, 2014), 28-29.

${ }^{9}$ The one exception was Democratic Arkansas AG Dustin McDaniel, who stated that he joined the lawsuit a month before leaving office only as a courtesy to his Republican successor.

${ }^{10}$ Amicus of States in Support of the United States, Texas v. United States, No. 15-40238 (5th Cir., filed April 6, 2015), 6; Amicus of States in Support of the United States, Texas v. United States, No. 15-674 (U.S. Sup. Ct., filed December 3, 2015), 3-8.

${ }^{11}$ Amicus of States in Support of the United States, Texas v. United States, No. 15-674 (U.S. Sup. Ct., filed December 3, 2015), 9-10.

${ }^{12}$ See, e.g., State of Hawaii v. Trump, Memorandum in Support of Plaintiffs' Motion for Temporary Restraining Order, No. 1:17-cv-00050-DKW-KJM (filed March 8, 2017).

${ }^{13} 74$ Fed. Reg. 66,496 (Dec. 15, 2009); 75 Fed. Reg. 31,514 (June 3, 2010).

${ }^{14}$ Petition for Extraordinary Writ, West Virginia v. EPA, No. 14-1112 (D.C. Cir., filed June 18, 2014).

${ }^{15}$ Amicus Brief Supporting Petitioner, West Virginia v. EPA, No. 14-1112 (D.C. Cir., filed June 25, 2014). The AGs represented West Virginia, Alabama, Indiana, Kansas, Kentucky, Louisiana, Nebraska, Ohio, Oklahoma, South Carolina, South Dakota, and Wyoming.

${ }^{16}$ Petition for Review, West Virginia v. EPA, No. 14-1146 (D.C. Cir., filed August 1, 2014).

${ }^{17}$ Settlement Agreement Between State of New York, et al., and U.S. EPA, December 23, 2010, http://www2.epa.gov/sites/production/files/2013-09/documents/boilerghgsettlement.pdf (last accessed November 12, 2016).

${ }^{18}$ Brief for State and Municipal Intervenors in Support of Respondents (filed March 29, 2016); Brief for Members of Congress as Amici Curiae in Support of Petitioners (filed February 23, 2016).

${ }^{19}$ Amicus Brief in Support of Preliminary Injunction, Exxon Mobil v. Healey, No. 4:16-cv-00469-A (N.D. Tex. September 8, 2016).

${ }^{20}$ Letter from Committee on Science, Space, and Technology to New York Attorney General, May 18, 2016, https://science.house.gov/sites/republicans.science.house.gov/files/documents/05.18.16\%20SST\%20Letter\%20to\%2 0NY\%20AG.pdf.

${ }^{21}$ Letter to Secretary Arne Duncan from Five U.S. Senators, November 17, 2015, https://www.mccain.senate.gov/public/index.cfm/2015/11/senators-alexander-mccain-demand-answers-for-federalagencies-unfair-targeting-of-university-of-phoenix-other-accredited-for-profit-institutions (last accessed November 12, 2016).

${ }^{22}$ See, e.g., State of Hawaii v. Trump, Memorandum in Support of Plaintiffs' Motion for Temporary Restraining Order, No. 1:17-cv-00050-DKW-KJM (filed March 8, 2017). 